UDC 616. 314 - 089. 23: 616. 98

Rybalov O.V., Skikevych M.G., Andriyanova O.Yu., Yatsenko P.I.

\title{
RESIDUAL PHENOMENA OF THE TRANSFERRED COVID-19 IN THE MAXILLOFACIAL REGION OR ITS COMPLICATIONS
}

\author{
Poltava State Medical University, Poltava, Ukraine
}

Today, the issues of the incidence of the Covid19 virus and its complications are extremely relevant in the scientific and everyday terms.

For about a year now, scientists and doctors have been trying to assess the outcomes that Covid-19 brings to the inhabitants of the whole world. Despite more than a million deaths, tens of thousands of studies carried out, this picture has not been fully clarified. It is believed that for some, the disease may only mean the beginning of a long and painful struggle with the virus, which may turn into a new "post-coronavirus syndrome" [1]. According to the authoritative journal Science, this coronavirus "does things that no other disease known to mankind has done" [2].

Much attention in the scientific literature is paid to possible complications such as sufferings of the lungs, heart. Along with this, it became known that the coronavirus can affect the brain, nasopharynx, eyes, blood vessels, liver, kidneys and intestines. That is, all vital organs are literally affected $[3,4,5]$.

We have interesting data from clinicians and morphologists. Those who have had Covid-19 note the long-term effects of scarring of the lung tissue and kidney failure, inflammation of the heart muscle, arrhythmias, liver damage, cognitive impairment, psychosis, accompanied by a sharp change in mood $[6,7]$.

Interesting observations from the Department of Systems Biology at George Mason University were seen: $70 \%$ of patients who have had Covid-19 rarely observe pathology of internal organs [8].

The really high incidence of this virus, the significant mortality of the population was the reason for the active efforts of the leading countries of the world to develop and use an antiviral vaccine $[9,10]$.

There is a lot of information in public media and daily reports about the frequency of cases of the virus, recovered, deceased and some other information. There is very little information in the scientific literature about the types of complications of the disease in the maxillofacial region.

The purpose of our work was to highlight the complications (or residual effects) from the large salivary glands after the patients suffered from Covid-19.

\section{Objects and research methods}

Our observations were carried out at the Poltava Center for Salivary Gland Pathology. There were only 17 patients. Three or four weeks ago, they reliably suffered from the disease. It has been identi- fied that the viral infection was moderate (13 people) and severe (4 people) severity. The patients' age ranged from 29 to 56 years. Along with general clinical information, the local status of the maxillofacial area was described. The function of the parotid salivary glands was studied using metal catheters, which were introduced into the mouth of the gland ducts for 10 minutes. The cellular composition of the secretion of the parotid glands was investigated according to the method generally accepted in cytology. 8 patients underwent ultrasound examination of the large salivary glands.

\section{Research results}

The patients who applied from 3-4 weeks ago completed observations associated with the presence of the viral Covid - 19 disease. The leading complaints were the next: temperature up to 38 39.5 degrees, adenoviral manifestations from the respiratory system, inadequate work of the gastrointestinal tract, renal disorders, and polyarthritis. The antiviral and symptomatic treatment given to the patients eliminated the leading symptoms of the disease. At the time of completion of treatment, general somatic symptoms were eliminated and they were discharged healthy.

When contacting our clinic, 3 patients complained of dryness in the mouth, especially at night and in the morning. 4 patients paid attention to dry mouth, burning sensation in the eye area. 5 patients, along with dryness in the mouth and nose, also had complete lack of food taste. 5 patients complained of appearance disorders. This was the main complaint. The parotid-masticatory areas were enlarged, we could observe dryness of the mucous membranes of the mouth and eyes. All patients had short-term or long-term headaches. Before the viral disease, none of the patients and their relatives had diseases of the salivary glands.

An examination of 8 patients did not reveal any facial asymmetry. Palpation revealed slightly enlarged parotid salivary glands, slightly compacted, slightly painful. The submandibular salivary glands were normal consistency and were painless. These patients had a moderate amount of oral fluid in the mouth. Saliva of normal viscosity was released from the ducts of the parotid and submandibular glands. With sialometry of the parotid glands, there was a slight drop in secretion to $1.5+0.3 \mathrm{ml}$ in 10 minutes. Cytological examination of the secretion of the parotid glands determined a small number of cells of the columnar epithelium. Some of these cells had a tendency to necro- 
sis; single squamous epithelial cells were found in the preparation.

In 4 patients, there was a slight increase in the parotid and submandibular salivary glands. Palpation revealed enlarged parotid salivary glands, compacted, painful in the lower areas. The submandibular salivary glands were slightly enlarged, palpated, slightly painful in the upper parts. The oral mucosa in these patients was moderately moistened. A small amount of saliva was secreted from the ducts of the parotid and submandibular glands, it was of increased viscosity. Parotid sialometry revealed a decrease in secretion to $1.2+0.5 \mathrm{ml}$ in 10 minutes. Cytological examination of the secretion of the parotid glands determined small complexes in 5 - 9 cells of neutrophilic leukocytes, a small number of cells of the columnar epithelium, some of which were in the stage of degeneration, groups of squamous epithelial cells with saprophytic flora.

5 patients had swollen tissues in the parotid region. Palpation revealed significantly enlarged parotid salivary glands. They were hard, bumpy, painful in all parts. The submandibular salivary glands were slightly enlarged and painless. The oral mucosa in these patients was poorly moisturized. A small amount of secretion was secreted from the ducts of the parotid and submandibular glands. The saliva was highly viscous. The mouths of the main ducts of the parotid glands were probed with difficulty. With sialometry of the parotid glands, a decrease in secretion to $1.1+0.2 \mathrm{ml}$ was noted in 10 minutes. Cytological examination of the secretion of the parotid glands determined single cells of neutrophilic leukocytes, macrophages, single lymphocytes, a small number of cells of the columnar epithelium, some of which were without cytoplasm, single cells of the squamous epithelium.

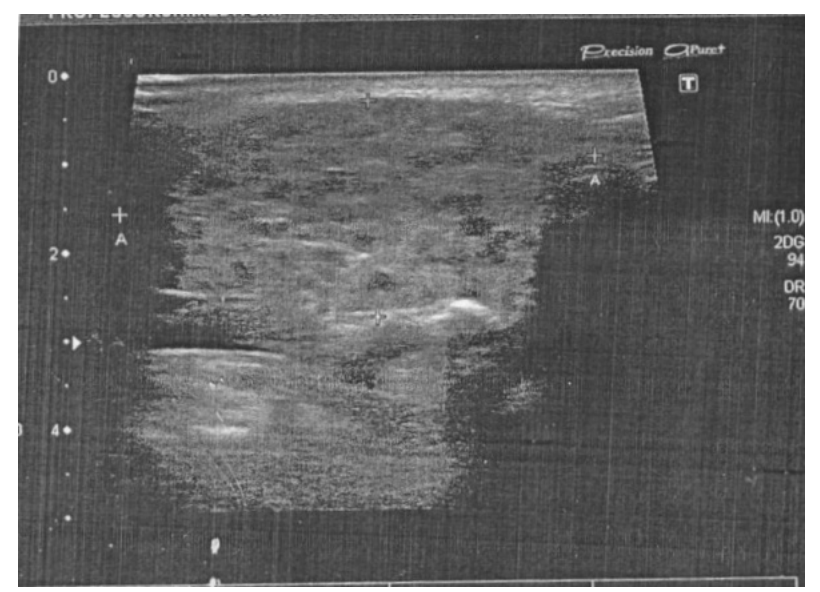

Fig. 1. Ultrasound of the left parotid salivary gland of patient J., 36 years old. The echo structure of the gland is not uniform, in the tissues there are areas of different echogenicity.

The blood flow is enhanced. Enlarged lymph nodes are presented with small anachogenic inclusions. Diagnosis - sialadenitis of the parotid gland.

\section{Results}

We evaluated the results of clinical examination data of 17 patients who had a viral Covid-19 infection and we observed them. In 3 - 4 weeks after re- covery, there were complaints: dryness of the mucous membranes of the mouth, nose, conjunctiva of the eyes, loss food taste, enlargement of the parotid and submandibular salivary glands. It is possible to reliably state that patients have clinical phenomena of sialopathy.

The results of additional studies of the secretion of the parotid glands, data of the cytology of their secretion and ultrasound examination confirm the fall of the secretory process in the glands of various degrees. The presence of elements of an inflammatory nature in the secret clearly defines the sialectatic process.

The presence of headaches in the examined patients determines their probable vascular disorders in the components of the brain. Such changes can indirectly affect the vascular complex of the salivary glands and be the cause of the development of duct contractures and the cause of sialadenosis.

The disorders we have identified in the salivary glands after the transferred Covid-19 virus serve as the basis for taking adequate measures to eliminate inflammation in the glands and restore the lost acinar and duct components.

The Center for Salivary Gland Pathology at the Department of Surgical Dentistry and Oral and Maxillofacial Surgery with Plastic and Reconstructive Head and Neck Surgery has extensive experience in examining and treating pathologies of the large salivary glands in various general somatic pathologies. The salivary glands are endocrine glands with endocrine functions. Therefore, all pathological processes in the human body are reflected in changes in their morphology and activity, including in the case of Covid-19 disease.

The outcomes of Covid-19 require more detailed study, especially about the types of consequences of diseases for the body.

\section{Perspectives}

In order to examine this category of patients, the study of the features of blood circulation in the vessels of the brain and salivary glands should be considered to clarify the pathogenesis of sialadenosis.

\section{Список літератури}

1. Никифоров ВВ, Суранова ТГ, Миронов АЮ, Забозлаев ФГ. Новая коронавирусная инфекция (COVID-19): этиология, эпидемиология, клиника, диагностика, лечение и профилактика. Москва: Академия постдипломного образования ФГБУ «ФНКЦ ФМБА России»; 2020. 48 с.

2. Holden Thorp H. A breakthrough for us all. Science. 2020 Dec 18; 370(6523):1381.

3. Козлов ИА, Тюрин ИН. Сердечно-сосудистые осложнения COVID-19. Вестник анестезиологии и реаниматологии. 2020;17(4):14-22.

4. Bernard I, Limonta D, Mahal LK, Hobman TC. Endothelium Infection and Dysregulation by SARSCoV-2: Evidence and Caveats in COVID-19. Viruses. Jan 2021; 13(1): 29.

5. Centers for Medicare \& Medicaid Services. Interim final rule updating requirements for notification of confirmed and suspected COVID-19 cases among residents and staff in nursing homes. Baltimore, 
MD: US Department of Health and Human Services, Centers for Medicare \& Medicaid Services; 2020. Available from: https://www.cms.gov/files/document/qso-20-29nh.pdf

6. CDC. Instructions for completion of the COVID-19 long-term care facility (LTCF) staff and personnel impact form (CDC 57.145). Atlanta, GA: US Department of Health and Human Services, CDC; $2020 . \quad$ Available from: https://www.cdc.gov/nhsn/pdfs/covid19//tcf/57.145toi-508.pdfpdf icon

7. CDC. Coronavirus disease 2019 (COVID-19): interim guidance for antigen testing for SARS-CoV-2. Atlanta, GA: US Department of Health and Human Services, CDC; 2020. Available from: https://www.cdc.gov/coronavirus/2019ncov/lab/resources/antigen-tests-guidelines.html

8. CDC. Coronavirus disease 2019 (COVID-19): guidance for testing, screening, and outbreak response for institutions of higher education (IHEs). Atlanta, GA: US Department of Health and Human Services, CDC; $2020.2 \quad$ Available from: https://www.cdc.gov/coronavirus/2019ncov/community/colleges-universities/ihetesting.html

9. Nikogosov DA, Shevlyakov AD, Baranova AV. Comment on "ApoE e4e4 Genotype and Mortality with COVID-19 in UK Biobank" by Kuo et al. The Journals of gerontology. Series A, Biological Sciences and Medical Sciences. 2020 Oct 01; 75(11):2233-4.

10. Скікевич МГ, Рибалов ОВ, Цитологічне дослідження секрету привушних залоз у хворих на хронічні неспецифічні захворювання легень. Матеріали I (VIII) з їзду асоціації стоматологів України; 1999 Лист 30 - Груд 2; Київ. Київ; 1999. с. 372.

\section{References}

1. Nikiforov VV, Suranova TG, Mironov AJu, Zabozlaev FG. Novaja koronavirusnaja infekcija (COVID-19): jetiologija, jepidemiologija, klinika, diagnostika, lechenie i profilaktika. Moskva: Akademija postdiplomnogo obrazovanija FGBU «FNKC FMBA Rossii»; 2020. 48 s. (Russian).

2. Holden Thorp $\mathrm{H}$. A breakthrough for us all. Science. 2020 Dec 18; 370(6523):1381.

3. Kozlov IA, Tjurin IN. Serdechno-sosudistye oslozhnenija COVID-19. Vestnik anesteziologii i reanimatologii. 2020;17(4):14-22. (Russian).
4. Bernard I, Limonta D, Mahal LK, Hobman TC. Endothelium Infection and Dysregulation by SARSCoV-2: Evidence and Caveats in COVID-19. Viruses. Jan 2021; 13(1): 29.

5. Centers for Medicare \& Medicaid Services. Interim final rule updating requirements for notification of confirmed and suspected COVID-19 cases among residents and staff in nursing homes. Baltimore, MD: US Department of Health and Human Services, Centers for Medicare \& Medicaid Services; 2020. Available

from: https://www.cms.gov/files/document/qso-20-29-nh.pdf

6. CDC. Instructions for completion of the COVID-19 long-term care facility (LTCF) staff and personnel impact form (CDC 57.145). Atlanta, GA: US Department of Health and Human Services, CDC; 2020. Available from: https://www.cdc.gov/nhsn/pdfs/covid19/ltcf/57.145toi-508.pdfpdf icon

7. CDC. Coronavirus disease 2019 (COVID-19): interim guidance for antigen testing for SARS-CoV2. Atlanta, GA: US Department of Health and Human Services, CDC; 2020. Available from: https://www.cdc.gov/coronavirus/2019ncov/lab/resources/antigen-tests-guidelines.html

8. CDC. Coronavirus disease 2019 (COVID-19): guidance for testing, screening, and outbreak response for institutions of higher education (IHEs). Atlanta, GA: US Department of Health and Human Services, CDC; 2020. Available from: https://www.cdc.gov/coronavirus/2019ncov/community/colleges-universities/ihetesting.html

9. Nikogosov DA, Shevlyakov AD, Baranova AV. Comment on "ApoE e4e4 Genotype and Mortality with COVID-19 in UK Biobank" by Kuo et al. The Journals of gerontology. Series A, Biological Sciences and Medical Sciences. 2020 Oct 01; 75(11):2233-4.

10. Skikevich MG, Ribalov OV, Citologichne doslidzhennja sekretu privushnih zaloz u hvorih na hronichni nespecifichni zahvorjuvannja legen'. Materiali I (VIII) z ïzdu asociaciï stomatologiv Ukraïni; 1999 List 30 - Grud 2; Kiïv. Kiïv; 1999. s. 372. (Ukrainian).

Стаття надійшла: 30.03.2021 p.

\section{Резюме}

Нині надзвичайно актуальним стало питання захворюваності населення на вірус Covid-19. Найчастіше описують ураження легень, серця, нирок, мозку, носоглотки, очей, кровоносних судин, кишечнику. Натомість відомостей про прояви патології в щелепно-лицевій ділянці в літературі мало.

Метою роботи стало висвітлення ускладнень (або залишкових явищ) із боку великих слинних залоз після перенесеного пацієнтами Covid - 19.

Об'єкти і методи дослідження. Спостерігали за 17 пацієнтами, які перенесли вірусну інфекцію. Поряд із загальноклінічною інформацією вивчали функцію привушних залоз, клітинний склад секрету, УЗД залоз.

Результати. Дослідження секреції привушних залоз, даних цитології секрету й ультразвукового дослідження підтверджують падіння їхньої функціональної активності, а наявність у секреті елементів запального характеру чітко визначають сіалектатичний процес. Виявлені порушення є основою для проведення адекватних заходів щодо усунення в залозах запальних явищ і відновлення ацинарних і протокових компонентів. Перспективний напрям - вивчення кровообігу судин головного мозку і слинних залоз для уточнення патогенезу виникнення сіаладенозу.

Ключові слова: Covid-19, ускладнення, слинні залози, симптоматика. 
UDC 616. 314 - 089. 23: 616.98

\title{
RESIDUAL PHENOMENA OF THE TRANSFERRED SARS-COV-2 IN THE MAXILLOFACIAL REGION OR ITS COMPLICATIONS
}

\author{
Rybalov O.V., Skikevych M.G., Andriyanova O.Yu., Yatsenko P.I.
}

Poltava State Medical University, Poltava, Ukraine

Today, the issues of the incidence of the Covid-19 virus and its complications are extremely relevant. Much attention in the scientific literature is paid to possible complications such as sufferings of the lungs, heart. Along with this, it became known that the coronavirus can affect the brain, nasopharynx, eyes, blood vessels, liver, kidneys and intestines. Interesting data from clinicians and morphologists has been received. Those who have had Covid-19 note the long-term effects of scarring of the lung tissue and kidney failure, inflammation of the heart muscle, arrhythmias, liver damage, cognitive impairment, psychosis, accompanied by a sharp change in mood. Interesting observations from the Department of Systems Biology at George Mason University were seen: $70 \%$ of patients who have had Covid-19 rarely observe pathology of internal organs.

The purpose of our work was to highlight the complications from the large salivary glands in the patients who suffered from Covid-19.

Objects and research methods. Our observations were carried out at the Poltava Center for Salivary Gland Pathology. There were only 17 patients. Three or four weeks ago, they reliably suffered from the disease. The function of the parotid salivary glands was studied using metal catheters, which were introduced into the mouth of the gland ducts for 10 minutes. The cellular composition of the secretion of the parotid glands was investigated according to the method generally accepted in cytology. 8 patients underwent ultrasound examination of salivary glands.

Results. The antiviral and symptomatic treatment given to the patients eliminated the leading symptoms of the disease. At the time of completion of treatment, general somatic symptoms were eliminated and they were discharged healthy. 3 patients complained of dryness in the mouth, especially at night and in the morning. 4 patients complained of dry mouth, burning sensation in the eye area. In 5 patients, along with dryness in the mouth and nose, there was a complete lack of sense food taste. 5 patients complained of disorders of appearance. The parotid-masticatory areas were enlarged, we could observe dryness of the mucous membranes of the mouth and eyes. All patients had short-term or long-term headaches. Before the viral disease, none of the patients and their relatives had diseases of the salivary glands. Physical examination in 8 patients did not reveal any facial asymmetry. Palpation revealed slightly enlarged parotid salivary glands, slightly compacted, and slightly painful. The submandibular salivary glands were of normal consistency and were painless. These patients had a moderate amount of oral fluid in the mouth. Saliva of normal viscosity was released from the ducts of the parotid and submandibular glands. With sialometry of the parotid glands, there was a slight drop in secretion to $1.5+0.3 \mathrm{ml}$. Cytological examination of the secretion of the parotid glands determined a small number of cells of the columnar epithelium. Some of these cells had a tendency to necrosis; single squamous epithelial cells were found in the preparation.

Conclusions. We evaluated the results of clinical examination data of 17 patients who had a viral Covid19 infection and they were examined by us. In 3 - 4 weeks after recovery, there were complaints: dryness of the mucous membranes of the mouth, nose, conjunctiva of the eyes, loss food taste, enlargement of the parotid and submandibular salivary glands. It is possible to reliably state that patients have clinical phenomena of sialopathy. The results of additional studies of the secretion of the parotid glands, data of the cytology of their secretion and ultrasound examination confirm the secretory process in the glands of various degrees. The presence of elements of an inflammatory nature in the secret clearly defines the sialectatic process. The presence of headaches in the examined patients determines their probable vascular disorders in the components of the brain. Such changes can indirectly affect the vascular complex of the salivary glands and be the cause of the development of duct contractures and leads to sialadenosis.

Perspectives. In order to examine this category of patients, the study of the features of blood circulation in the vessels of the brain and salivary glands should be considered to clarify the pathogenesis of sialadenosis.

Key words: Covid-19, complications, salivary glands, symptoms. 